\title{
Formulation, Nutritive Value Assessment and Effect on Weight Gain of Infant Formulae Prepared from Locally Available Materials
}

\author{
Johnson Joel Theophilus ${ }^{1, ~}$, Atule Rebecca Ashi ${ }^{2}$, Gbashi Sefater ${ }^{3}$, Ogbolosingha Atieme Joseph ${ }^{1}$ \\ ${ }^{1}$ Department of Biological Sciences, Faculty of Science, Federal University Otuoke, Bayelsa State, Yenagoa, Nigeria \\ ${ }^{2}$ Department of Biochemistry, College of Natural and Applied Sciences University of Mkar, Mkar, Gboko Benue State, Nigeria \\ ${ }^{3}$ Department of Biotechnology and Food Technology, Faculty of Science, University of Johannesburg, South Africa
}

Email address:

theophjoe@yahoo.com (Johnson J. T.)

\section{To cite this article:}

Johnson Joel Theophilus, Atule Rebecca Ashi, Gbashi Sefater, Ogbolosingha Atieme Joseph. Formulation, Nutritive Value Assessment and Effect on Weight Gain of Infant Formulae Prepared from Locally Available Materials. Journal of Food and Nutrition Sciences.

Vol. 3, No. 1, 2015, pp. 39-46. doi: 10.11648/j.jfns.20150301.16

\begin{abstract}
The widespread problem of infant malnutrition in developing countries has stirred efforts in research, development and extension by both local and international organizations. As a result, the formulation and development of nutritious weaning foods from local and readily available raw materials, which are cost effective has become imperative in many developing countries. Thus, the local and readily available raw materials were used to compound and develop nutritious new infant formulae. The materials used for this study include maize, millet, cowpea, pumpkin, fingerlings and fish bone. The materials were dried and blended to powder. The powders were weighed in the ratio of 4:4:4:3:1:1 respectively and were then mixed properly. Analysis of nutritive value was performed on the formulae and compared with NAN-2 (control) and results revealed that the formulae had reasonable amount of moisture, lipids, carbohydrate, protein and fibre. Although NAN-2 was superior in carbohydrate and protein, our infant formula was higher in mineral elements, vitamins, fibre and lipids. All the essentials vitamins and both macro and micro minerals were found in appreciable quantity capable of meeting the biochemical and physiological demand of the body while the anti-nutrients composition were significantly $(\mathrm{p}<0.05)$ below FAO and WHO safe limits. Finally, the compounded infant formulae was feed to a set of albino wistar rats, while some other set of rats was feed with NAN-2 for the period of twenty seven (27) days and body weight gains were measure at three days intervals. The results of body weight changes was spectacular as their body weight over shot or almost double that of those animals that were feed with NAN-2 at each point of measurement. The results suggest that the widespread problem of infant malnutrition in the developing world especially among the low income segment of the society can now be reduced, if not totally eradicated since nutritive and cost effective weaning formulae can be prepared locally from common readily available materials.
\end{abstract}

Keywords: Formulation, Nutritive-Value, Weight-Gain, Infant-Formulae, Local-Material

\section{Introduction}

Throughout much of human evolution, it is likely that large amounts of plant foods were and are being consumed Jane, (2005). In addition to being rich in fiber and plant protein, the diets of our ancestors were also rich in phytochemicals. The widespread problem of infant malnutrition in the developing world has stirred efforts in research, development and extension by both local and international organizations. As a result, the formulation and development of nutritious weaning foods from local and readily available raw materials which are cost effective have received a lot of attention in many developing countries. Malnutrition is a major health problem in developing countries and contributes to infant mortality, poor physical and intellectual development of infants, as well as lowered resistance to disease and consequently stifles development. Protein-energy malnutrition generally occurs during the crucial transitional phase when children are weaned from liquid to semi-solid or fully adult foods. During this period, children need nutritionally balanced, calorie-dense supplementary foods in addition to mother's milk because of the increasing nutritional demands of the growing body (Cameroon and Hofvander, 1971; Berggren, 1982; Sajilata et al, 2002; Umeta et al, 2003). Thus, weaning food plays a vital 
role in the all round growth, development and mental health of children.

Generally, foods eaten in developing countries contain high levels of carbohydrate with very low or no proteins due to the high cost of protein rich foods and some traditional beliefs about feeding infants with protein foods. Apart from protein and energy, weaning diets of infants in developing countries require more calcium, vitamin $\mathrm{A}$ and $\mathrm{D}$, iron and some important trace elements. These can be obtained by combining the local staples presently available in the country. Combination of commonly used cereals with inexpensive plant protein sources like legumes can be use. Cereals are deficient in lysine, but have sufficient sulphur containing amino acids which are limited in legumes (Tsai et al, 1975; Wang and Daun, 2006; Iqbal et al, 2006; Shewry, 2007) whereas legumes are rich in lysine. The effects of the supplementation are highly beneficial, since nutritive value of the product is also improved and nutritional status of the consumers are assured.

Hunger or other nutritional related problem most especially among the infant have remain and continue to threaten infant's health and existence. Problem of nutrition during weaning period are complex and sometime complicated by many environmental factors. For example, early childhood infection, poverty of parents and ignorance among the population are some of the factors that affect the type of local weaning food. The problem of the developing a compromised immune system among poorly nourish infant must be weighed against the essential goal of good nutritional health; that is to reduce morbidity and mortality among infants. Thus a balance must be reached that attempts to achieve both goals whilst not compromising either too much by doing so. However, the type of weaning formula employed for weaning depends on the resources within the locality under consideration. Thus, all these have contributed to the widespread problem of infant malnutrition in the developing world including Nigeria. The most successful attempts so far have been in the administration of combined formulated supplement and mixed which are even expensive and may not be affordable by poor parents living below poverty line in most developing countries. Hence, this studies is justify by the fact that it will improve on the quality of the traditional weaning foods which is important to supply more available proteins, vitamins, minerals and all round nutrients required for growth and general wellbeing of a weaned child since it aimed at combining local and readily available raw materials which are inexpensive to develop nutritious new infant formulae with long shelf life and overall consumer's acceptability but at the same time cost effective.

The scope of this study covers; the formulation of new infant formulae base on locally available materials like millet, cowpea, pumpkin (cacurbita pepo'l), maize, dry flesh and ashed bones of fingerlings (fish), determination of antinutrients content, nutrients composition of the formulae and comparing it to commercial available formulae (NAN-2), feeding of the formulation and commercially sold formulae (NAN-2) to animal rat model to determined their growth rate.

\section{Materials and Methods}

\subsection{Materials}

The materials used for this work include millet, maize, cowpea, pumpkin, fingerlings.

\subsection{Source of Materials}

Millet, maize, cowpea, pumpkin and fingerlings was obtained from Wurukum market Makurdi, Benue State Nigeria.

\subsection{Preparation}

\subsubsection{Preparation of Maize Flour}

The maize was sorted for stones, rot and other physical defects. The grains without defects was cleaned and roasted under an open flame until golden brown. The roasted maize was allowed to cool, milled with a hammer mill and sieved to obtain the flour.

\subsubsection{Preparation of Millet Flour}

The millet was screened for stones, rot and other defects, cleaned, dried and milled and sieved to obtain the flour.

\subsubsection{Preparation of Fish Bone Meal}

Fingerlings was cleaned and dried to flakes to remove the moisture content. The flesh was removed and blended into powder and the bone was also milled to obtain the meal and the bone was further ash to obtain the calcium content.

\subsection{Constitution of the Formulae}

The formulae was constituted by mixing maize, millet, cowpea, pumpkin, fish and fish bone powder together in ratio 4:4:4:3:1:1 respectively and was mix properly using a mechanical mixer to obtained an homogenous mixture.

\subsection{Determination of Proximate/Energy Composition}

Percentage moisture crude protein, crude fat, crude fiber and ash content of the formulation were determined based on the official methods of analysis (AOAC, 2012). Percentage carbohydrate was determined by difference. The food caloric value was determined by calculation using the Atwater factor. (Southgate and Durnin, 1970).

\subsubsection{Moisture Contents}

Moisture content was reported as the loss in known weights of the samples upon drying in a hot air circulating oven (Gallenkamp hot box) at $50^{\circ} \mathrm{C}$ for 24 hours.

\subsubsection{Ash Content and Organic Matter}

The weight of the ash was determined after incineration of the sample in a muffle furnace at $550^{\circ} \mathrm{C}$ until ash was obtained. The percentage of material burnt off was regarded as the organic matter.

\subsubsection{Crude Fibre}

Crude fibre was determined from the loss in weight on ignition of dried residue remaining after digestion of fat free 
sample with $1.25 \% \mathrm{H}_{2} \mathrm{SO}_{4}$ solution and $1.25 \% \mathrm{NaoH}$ solution under specified conditions (Joslyn, 1970).

\subsubsection{Crude Protein Content}

The Crude protein was determined by the macro-kjeldahl method (AOAC 1991). It determines nitrogen content of protein by digestion, distillation and titration.

Protein with concentrated sulphuric acid in the presence of a catalyst was liberated as ammonia by addition of sodium hydroxide $(\mathrm{NaoH})$ followed by distillation. The amount of ammonia liberated was trapped in boric acid and estimated by titration using standard hydrochloric acid to have a purple pink end point.

\subsubsection{Crude Fat}

The lipid in the sample was determined by exhaustively extracting known weights of the samples with petroleum ether (bp $40-60^{\circ} \mathrm{C}$ ) using soxhlet apparatus for 6 hours. The amount of lipid in the sample was obtained by subtracting its weights after extraction from that before extraction.

\subsubsection{Carbohydrate Content}

The carbohydrate content was obtained by subtracting the sum of protein, fat, ash and fibre from the $100 \%$.

\subsubsection{Caloric Value}

The caloric value was obtained by multiplying the values of crude protein by $4 \mathrm{~g}$, lipids by $9 \mathrm{~g}$ and carbohydrate by $4 \mathrm{~g}$ and taking the sum of the products.

\subsection{Determination of Vitamins}

The vitamins in the samples were determined using the methods of association of vitamin chemists (AOVC 2013) vitamin $A$ and $B$ were determined using the spectrophotometer method described by Kirk and Sawyer, (1991) at 325nm. Vitamin B (Niacin, thiamin and Riboflavin) was determined using a flame photometer while viyamin $\mathrm{C}$ was estimated by the 24 dinitrophenol hydrazine methods as described in (AOAC 1966).

\subsection{Determination of Minerals}

The mineral composition in the fresh and dry samples was determined using the dry ash method James (1995).Calcium and Magnesium were determined by the versanate EDTA complexiometric titrimetry. Sodium and Potassium were determined using a flame photometer.Phosphorus was obtained by the variable - molybdete colorimetric method. Determination of heavy metals was done by the atomic absorbtion spectrophotometry (AAS) according to James (1995).

\subsubsection{Test for Tannins}

This was done by the ferric chloride test described by Harbone (1973). Ferric Chloride and $\mathrm{K}_{3} \mathrm{Fe}(\mathrm{CN}) 6$ were used to develop the colour of tannin extracted from the sample and absorbance taken at wave length $710 \mathrm{~nm}$.

\subsubsection{Oxalate}

The Method of Munro \& Bassir (1969) a modified method of Dye (1956) was used. The oxalic acid was extracted from the sample and precipitated as calcium salt. The oxalate was then dissolved in sulphuric acid and concentrations of oxalate in the solution determined by titration with $\mathrm{K}_{2} \mathrm{Mno} 4$ for a faint pink end point.

\subsubsection{Hydrocyanic Acid}

This was done using the method of Balogoplan (1998) the alkaline picrate colorimeter method. The sample was dissolved in $200 \mathrm{mls}$ of distilled water and a picrate paper (yellow) was suspended over the mixture and incubated at room temperature for 18 hours. The picrate paper was diluted in $60 \mathrm{mls}$ of distilled water and the diluents were measured at $540 \mathrm{~nm}$.

\subsubsection{Phytate}

The spectrophotometer method as described by (Onwuka, 2005) and Oberleas, 1978) was employed. The sample was mixed with $60 \mathrm{mls}$ of $0.2 \mathrm{M} \mathrm{Hcl}$ and shaken for 30 minutes before boiling in water bath for another 30 minutes and cobled in ice water for 15 mintues. $2 \mathrm{mls}$ of 2, 2-Biphydine solution was added to the mixture and mixed thoroughly. Their respective absorbances were measured with a mixture of pyridine addition. Absorbance was measured at 500$520 \mathrm{~nm}$.

\subsection{Assesment of the Effect of the Formulae on Body Weight}

Our locally made formulae and the commercially available formulae (NAN-2) were feed to two different experimental groups using animal rat model. Their weight was measured using electronic weighing balance and recorded and compared at 3 days interval for 21 days and this was compared with animals that were place on regular rat pellet to evaluate the growth rate.

\subsection{Statistical Analysis}

Data obtained was expressed as Mean \pm Standard Deviation and analyzed using the Analysis of Variance 'ANOVA; f-ratio' (Welkowitz, et al.,2006) and Statistical Package for Social Scientists (SPSS version 18). Values at $\mathrm{P}<0.05$ were regarded as significant in comparison with appropriate controls.

\section{Results}

\subsection{Proximate Composition}

The results of the moisture, ash, protein, lipids, fibre and carbohydrate content of NAN and our local formulation is presented in figure 1. The statistical analysis reveals that NAN had a higher protein and carbohydrate compared to our formulae. However, our formulation recorded a significant $(p<0.05)$ high values for moisture, lipids and fibre while the ash content of both samples compares favourably well with each other. 


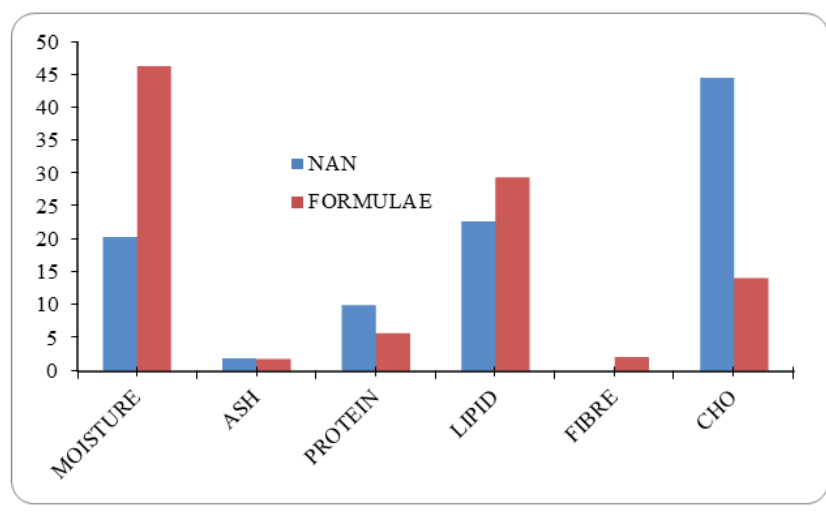

Figure 1. Proximate composition (NAN/LOCAL FORMULATION).

\subsection{Vitamin Contents of Nan and Local Formulation}

The results of the vitamins content both NAN and our local formulation are presented in figure 2. Figure 2 shows that pro-vitamin A and ascorbic content of NAN was higher that of our formulations while thiamine, riboflavin and folic acid where all higher in our formulation when compared with NAN. However, niacin, cyanocorbalamin, pyroxal phosphate, cholecalferol, tocupherol levels of both weaning formulations compared favourably with each other.

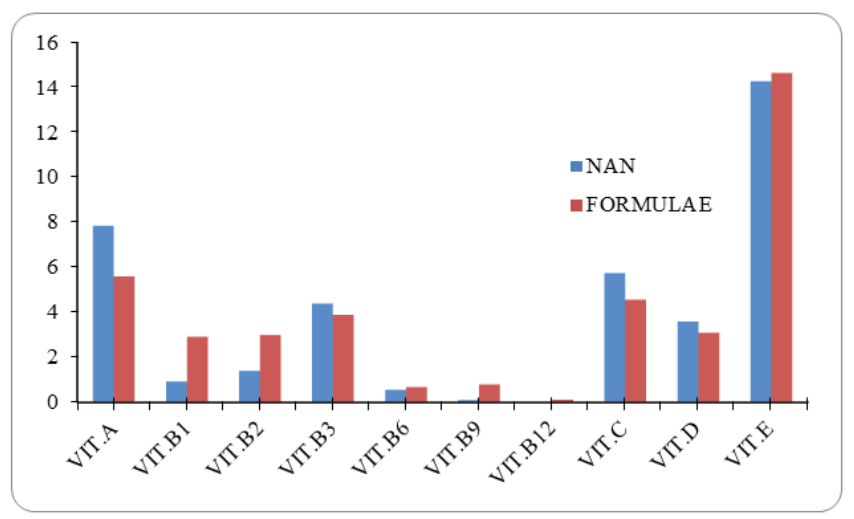

Figure 2. Vitamins composition (NAN/LOCAL FORMULATION).

\subsection{Anti-Nutrient Composition of the Locally Made Formulae}

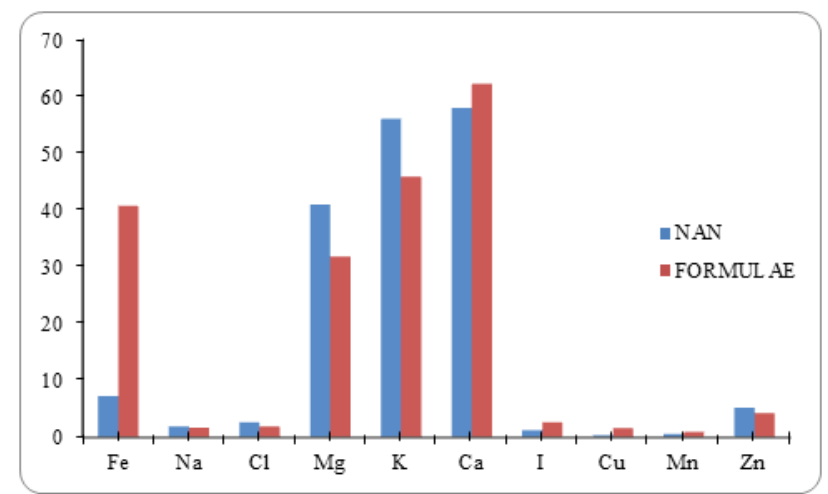

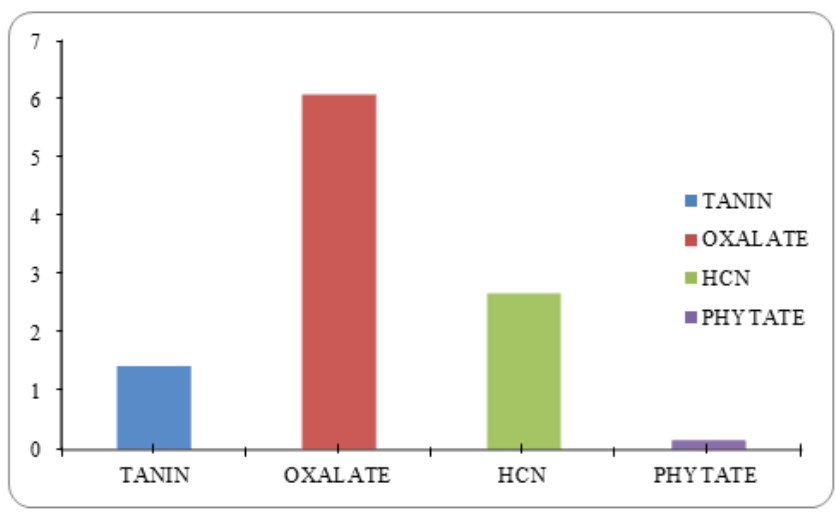

Figure 4. Anti-nutrient content of LMF.

The results of the Anti-nutrient present in our LMF are presented in figures and the results the presence of phytate, HCN, tannins and oxalate. The level of phytate was infinitesimal followed by $\mathrm{HCN}$, tannins and oxalate in an increasing order.

\subsection{Body Weight Changes}

The body weight changes of wistar rats feed with rat pellet, commercially weaning formulae (NAN-2) and locally made formulae (LMF) is presented in figure 5-7.

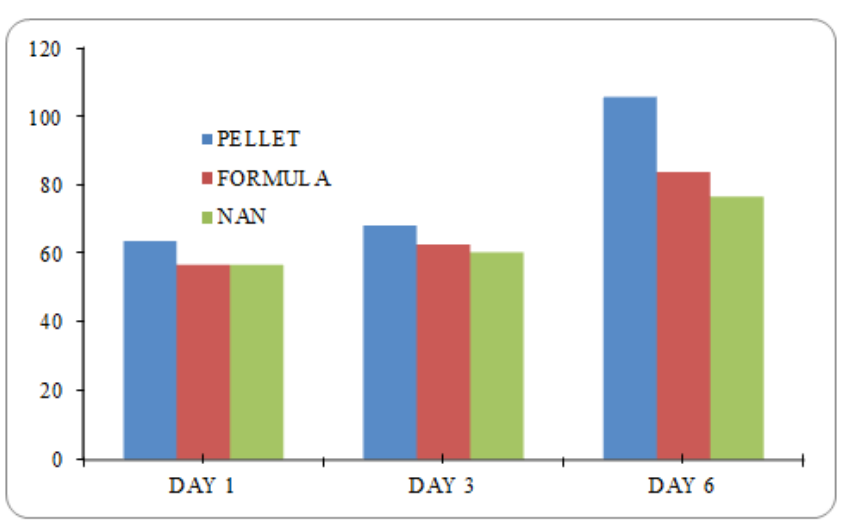

Figure 5. Body weight changes; Day 1-6.

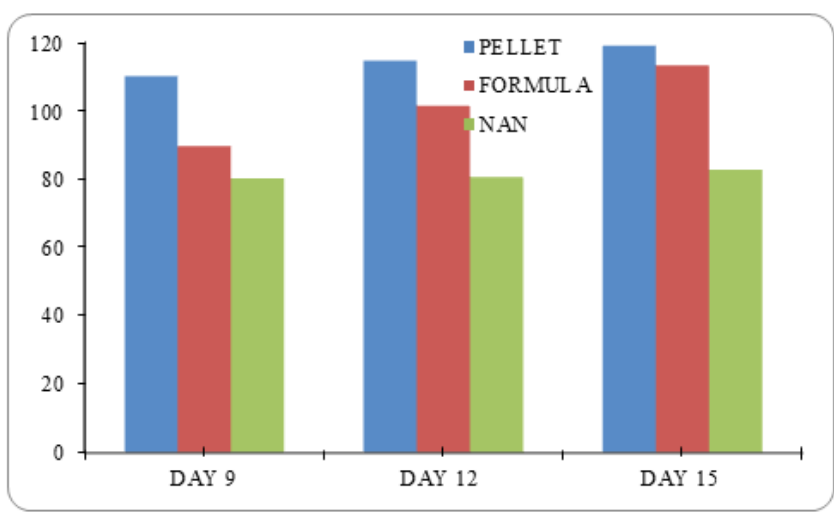

Figure 6. Body weight changes; Day 9-15.

Figure 3. MINERAL COMPOSITION OF NAN/LOCAL FORMULATION. 


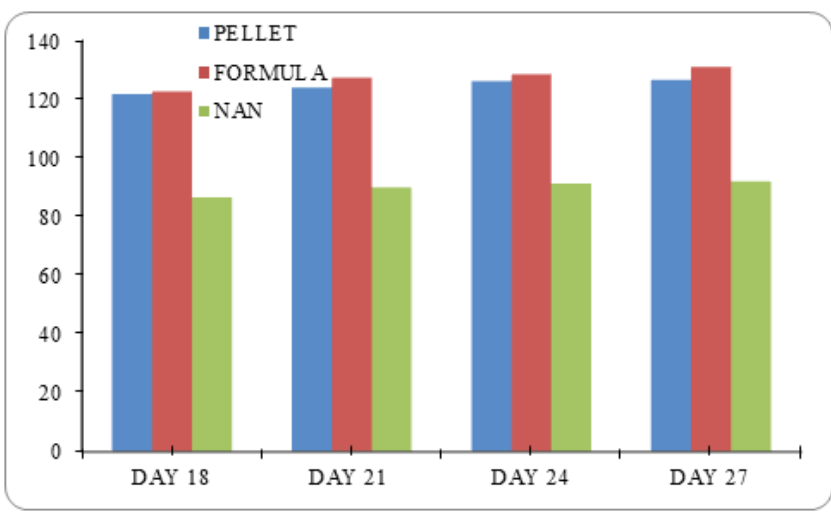

Figure 7. Body weight changes; Day 18-27.

At day one to three, the weight of all three groups compares well with each other. However, slight changes where noticed at day six where those feed with pellet showed high value followed those feed with LMF and then NAN.

On day fifteen, the weight of animals feed with LMF compares very well with those feed with rat pellet while the group that was feed recorded lower weight value at day fifteen.

More so, from day eighteen till day twenty seven, the weight of animals in groups feed with LMF overshot that of other groups.

\section{Discussion}

Locally made weaning formulae was compose from cheap and readily locally available materials (millet, yellow maize, cowpea, pumpkin and fingerlings) in Benue State Nigeria and the nutrients and anti-nutrients compositions of the formulae was analyzed and values obtained were compared with that of commercially available weaning formulae (NAN).

The values of proximate composition reveal high moisture, fibre and lipid for LMF which was lower in NAN. The high moisture and fibre values seem to be healthy since it will prevent constipation. However, the protein and carbohydrate which was found to be higher in NAN than LMF indicated reason behind high caloric index for NAN. The slightly lower caloric value for LMF must have been due to high fibre value. This agrees with the findings of Potter and Hotchkiss (1997), Osse (1990), shiela (1978), Bollard (1970), Tindall (1994) and Pamplona (2008) who worked on nutrient components of local food prepared from maize, cowpea, millet etc.

The results of vitamin and minerals content of LMF shows that it has high thiamine, riboflavin and folic acid value while other vitamins compares well with that of NAN. This is a strong indication that the energy domicile in the compose formulae can be properly utilized with the aid of thiamine being a co-enzyme for pyruvate decarboxylase. The vitamin $\mathrm{A}, \mathrm{C}$ and $\mathrm{E}$ serve anti-oxidant role while the ascorbic acid also aid in building connective tissues and cholecalciferol is pivotal in the absorption of calcium.

According to Anderson (1966) fruits when fresh provides vitamin $\mathrm{C}$ which is essential for strong blood vessels and healthy gums, but results from this study has shown that dry fruits also contain an appreciable amount of vitamins as in fresh fruits, which agrees with Pamplona (2008) who stated that fresh ripe fruits evidently provides the greatest level of vitamin, flavonoids and antioxidants but if not available, it is always better to eat fruits that has been preserved by some methods than not to eat it at all.

The minerals results also shows that LMF had a very iron level while the values of other minerals compares well the values in NAN-2. Higher content of macro minerals; magnesium, potassium phosphorus and micro minerals, iron and zinc in our formulation recorded in this study is similar with earlier works by El-Adaway (2004), USDA (2003). High content of potassium was recorded in the LMF and (Murkovic et.al. 2002) reported that cowpea, millet and some aquatic life contained considerable amount of phosphorus, potassium, magnesium, manganese and calcium. This might be as a result of the mineral content of the soil where the crop was grown as stated by FAO (1984).

Four different anti-nutrients of varying levels were found in the local formulation. There were tannins,oxalate, $\mathrm{HCN}$ and phytates with values ranging from $1.8 \mathrm{ug} / 100 \mathrm{~g}, 6.9 \mathrm{ug} / 100$, $3.2 \mathrm{ug} / 100 \mathrm{~g}$ to $0.3 \mathrm{mg} / 100 \mathrm{~g}$ respectively and these values were below FAO recommended tolerable levels. For example, $15 \mathrm{mg} / \mathrm{kg}$ for tannins, the oxalate level is also within the tolerable limit for man $1020 \mathrm{ppm} / \mathrm{kg}, 0.02 \mathrm{mg} / 100 \mathrm{~g}$ for hydrocyanide and phytic acid $0.74 \mathrm{mg} / 100 \mathrm{~g}$ (Brandbury, 1991; Onwuka, 2005).

Francis (2001) indicated that tannins can interfere with digestive processes by bindingto feed proteins, vitamins, minerals and digestive enzymes. Dietary hydrolysabletannins was also reported to retard growth. The presence of high concentration levels oftannins therefore implies possibilities of poor protein digestibility caused by formation of protein tannin complexes which irreversibly bind digestive enzymes, thus inhibiting the activities of the enzymes making them unavailable for breaking down proteins with the resultant effect that proteins and other nutrients are liable to escape digestion. The presence of high concentration of tannins also indicate possibilities of poor palatability of feed due to bitter tastes hence reduction in feed intake (Akinmutimi, 2004). Patridge et al. (1982), Cherbut et al. (1998) and Akinmutimi et al. (2009) also reported that high tannin contents depresses cellulase activity by binding fibre, thus affecting bio degradability (digestibility). Hydrogen cyanides the hydrolysed toxic products of cyanogens suppress natural respiration and cause cardiac arrest (Davies, 1991). The presence of cyanide inhibits action of porhyrin enzymes (cytochrome oxidase in tissues and rapidly leads to suffocation).

Oxalate and calcium is known to interfere with calcium absorption by forming in-soluble salt with calcium, thus making it unavailable for use by the body while phytate binds iron out as iron phytate making it unavailable (Umar, 2006). More so, studies have shown that high vitamin $\mathrm{C}$ levels can liberate iron from phytate. However, alkaloid, saponins were not detected. 
The results of body weight changes shows that wistar rats that were feed with LMF recorded a steady growth rate in terms of body weight changes throughout the twenty seven days period and the body weight at day twenty seven over shot feed with rat pellet and NAN-2. This shows that the nutrient domicile in our locally compose formulae can be essential for a growing infant that has been weaned from breast milk.

\section{Conclusion}

The major purpose of this study was to compose weaning formulae from local and readily available raw materials which are inexpensive to develop, nutritious new infant formulae with long shelf life and overall consumer acceptability but at the same time cost effective while comparing it with the commercially available weaning formulae (NAN-2). It explored the chemical evaluation and anti-nutrient contents of the two formulae. It was also the interest of this study to evaluate the mineral elements and vitamin contents of the formulars. Finally, the results obtained from this study have shown that the LMF have good levels of protein, lipids, fibre, carbohydrate and calories. While both macro and micro minerals were also present in abundant alongside water and fat soluble vitamins. All these contributed to excellent growth rate measure via weight changes recorded for animals feed with this formulation. More so, no changes on the physiochemical property of the formulae till date. Hence, this formulae (LMF) appears to be healthy and reliable to be used as weaning formulae for the local populaces who leaves below the poverty line and thus, cannot afford the commercially available weaning formulae.

\section{References}

[1] James, A.S. (2005). Biological Specification for FoodPrinciples and Specific Applications, University of TorontoPress, Canada.

[2] Cameroon, M. and Y. Hofvander, 1971. Manual on Feeding Infants and Young Children, P.A.G. Document; 14: 25-26.

[3] Berggren, G.G., 1982. Questions and answers about weaning. Food Nutr. Bull., 4: 20-24.

[4] Sajilata, G., Singhal, R.S. and Kulkarni, P.R. (2002).Weaning foods: A review of the Indian experience. Food Nutr. 23: 208226.

[5] Tsai, C.Y., A. Dalby and R.A. Jones, 1975. Lysine and Rombouts, F.M. and M.J.R. Nouts, 1995. Microbial Tryptophan Increase during Germination of Maize Fermentation in the Production of Plant food, J. Seed, Cereal Chem., 52: 356-360. Appl. Bacteriol., 79: 1085-1175.

[6] Wang, N. and K.J. Daun, 2006. Effect of Variety and Food Fabricated from Fermented Blends of Cereal Crude Protein Content on Nutrients and Antiand Soybean, J. Food Chem., 65: 35-39. nutrients in Lentils (Lens culinaris), J. Food Chem.,

[7] Iqbal, A., A. Ateeq, I.A. Khalil, S. Perveen and S.
Saleemmullah, 2006. Physicochemical Characteristics and Amino Acid Profile of Chickpea Cultivars grown in Pakistan, J. Food Service, 17: 94-101.

[8] Shewry, P.R. (2007). Improving the protein content and composition of cereal grain. J. Cereal Sci., 46: 239-250.

[9] AOAC, (2012). Official Methods of Analysis, Association of Analytical Chemists, International 14th Edn, Washington DC, pp: 22: 113-114, 169: 207-208.

[10] Sothgate, G.K. and Duranin, J.H. (1970). Biological Specification for Food-Principles and Specific Applications, University of Toronto Press, Canada.

[11] Joslyn, C. A. (1970). Food and Agriculture Organization. World Health Organization bulletin, 15-58.

[12] Kirk, R.S. and Sawyer, R. (1991). Pearson's composition and analysis of foods. Longman Scientific and technical. Harllow. Essex.

[13] Harborne, J.B (1973). Phytochemical methods, London. Chapman and Hall, Ltd. 49.

[14] Munro, A. and Bassir, D (1969). Oxalates in Nigerian vegetables. West Afr. J. Biol. Applied Chem., 12:14-18.

[15] Balogoplan, C. (1998). Cassava in food, feed and industry: CRC press incorporation. Florida. 187-189

[16] Onwuka, G.I. (2005). Food Analysis and Instrumentation. Theory and practice. Naphtali prints Lagos, Nigeria. Pp. 133137

[17] Oberleas, D. (1978). Micronutrients in metabolism and diseases. J. Nutr. 20, 56.

[18] Welkowitz, J., Barry, H.C. \& Robert, B. E. (2006). Introductory Statistics for Behavioural Sciences. John Wiley and Sons Publishing: Howard press.

[19] Potter, N.N. and Hotchkiss, J. H. (997). Food Science. University of Missouri. USA

[20] Osse, J. (1990). Netherland Journal of Zoology. 50 (2) 89-99

[21] Tindall, K.R. (1994). Introduction to the Chemical Analysis of Foods, International Thomson Publishing, New York, 93-96, 113-115, 137-148. Pak. J. Nutr., 8 (11): 1747-1752, 2009, 1752

[22] Pamplona, H. E. (2008). Development of Weaning Food Formulations based on Cereal, International J.Food Sci. and Technol., 24-28.

[23] El-adaway, A.C. (2004). Effect Of Temperature on Polyunsaturated Fatty Acid Accumulation In Soybean Seeds, Brazilian J. Plant Physiol., 17.

[24] Mirkovic, I., Charish, k., Gorski, S.M., McKnight, K., Verheyen, E.M. (2002). Drosophilia nemo is an essential gene involved in the regulation of programmed cell death. Mech. Dev. 199(1):9-20.

[25] FAO, WHO. (1982). Codex Standards for Foods for Special Dietary Uses Including Foods for Infants andChildren and Related Code of Hygienic Practice,

[26] Akinmutimi, A.H. (2004). Evaluation of sword bean (canavalia gladiata) as an alternative feed source for broiler chiken. Ph.D Thesis. Micheal Opara University of Agriculture, Umudike, Nigeria. 
[27] Akinmutimi, A.H., Ojewola, G.C., Abasiekong, S.F. andOnwudike, O.C (2008). Evaluation toasted, cooked and Akanwu cooked sword beans meal in place of soya bean meal in broiler stater diets. Int. J. poult. Sci. 7(5)480-486

[28] Umar, M.J. (2006). Improvement of the nutritional quality of a traditional complementary porridge made of fermented yellow maize (Zea mays): effect of maize-legume combinations and traditional processing methods. Food Nutr Bull. 28(1):23-34.

[29] Publishing, New York, 93-96, 113-115, 137-148. Pak. J. Nutr., 8 (11): 1747-1752, 2009, 1752

[30] Ngeh-Ngwainbi, J., J. Lin and A. Chandler, 1997. Southgate, D.A.T. and J.V.G.A. Durnin, 1970. Calorie Determination of Total, Saturated, Unsaturated and Conversion Factors. An experimental Monounsaturated Fats In Cereal Products by Acid Reassessment of the Factors Used in the Hydrolysis and Capillary Gas Chromatography: Calculation of the Energy Value of Human Diets, Br. Collaborative Study, J. AOAC Int., 80: 359-372. J. Nutr., 24: 517-535.

[31] Oduro, I., W. Ellis, A. Sulemana and P. Oti-Boateng, Szalai, G., T. Janda, E. Páldi and J. Dubacq, 2001. 2007. Breakfast Meal from Breadfruit and Soybean Changes In the Fatty Acid Unsaturation after Composite, Discovery and Innovation, 19: 238-242. Hardening in Wheat Chromosome Substitution Protein Advisory Group, 1972. Guidelines of Protein Lines with Different Cold Tolerance, J. Plant Rich Mixture For Use In Weaning Foods. Protein Physiol., 158: 663-666. Advisory Group. New York, 50.

[32] Sanni, A.I., A.A. Onilude and T.I. Ibidapo, 1999. 1069. Biochemical Composition of Infant Weaning

[33] Shewry, P.R., 2007. Improving the Protein Content and 95: 493-502

[34] Onwuka, G.I. (2005). Food Analysis and Instrumentation. Theory and practice. Naphtali prints Lagos, Nigeria. Pp. 133137

[35] Kirk, R.S. and Sawyer, R. (1991). Pearson's composition and analysis of foods. Longman Scientific and technical. Harllow. Essex.

[36] Balogoplan, C. (1998). Cassava in food, feed and industry: CRC press incorporation. Florida. 187-189

[37] Munro, A. and Bassir, D (1969). Oxalates in Nigerian vegetables. West Afr. J. Biol. Applied Chem., 12:14-18.

[38] Osse, J. (1990). Netherland Journal of Zoology. 50 (2) 89-99

[39] Potter, N.N. and Hotchkiss, J. H. (997). Food Science. University of Missouri. USA

[40] Mirkovic, I., Charish, k., Gorski, S.M., McKnight, K., Verheyen, E.M. (2002). Drosophilia nemo is an essential gene involved in the regulation of programmed cell death. Mech. Dev. 199(1):9-20.

[41] Akinmutimi, A.H. (2004). Evaluation of sword bean (canavalia gladiata) as an alternative feed source for broiler chiken. Ph.D Thesis. Micheal Opara University of Agriculture, Umudike, Nigeria.

[42] Akinmutimi, A.H., Ojewola, G.C., Abasiekong, S.F. andOnwudike, O.C (2008). Evaluation toasted, cooked and Akanwu cooked sword beans meal in place of soya bean meal in broiler stater diets. Int. J. poult. Sci. 7(5)480-486
[43] Lu, H., Zhang, J., Liu, K.B., Wu, N., Li, Y., Zhou, K., Ye, M., Zhang, T. (2009). "Earliest domestigation of common millet (pannicum miliaceum) in East Asia extended to 10,000 years ago". Proceedings of the National Academy of Sciences of the United States of America 106 (18): 7367-72

[44] McDonough, C. M., Rooney, L. W., and Serna-Saldivar, S. O. (2000). "The Millets"; Food Science and Technology: Handbook of Cereal Science and Technology

[45] Piperno, D.R., Ranere, A.J., Holst, I. (2009). Starch grain and phytolith evidence for early ninth millennium B.P. maize from the Central Balsas River Valley, Mexico. Proc Natl Acad Sci U S A. 106(13):5019-5024.

[46] Kean, E.G., Hamaker, B.R. and Ferruzzi MG. (2008). Carotenoid bioaccessibility from whole grain and degermed maize meal products. J Agric Food Chem. 56(21): 9918-9926.

[47] Ranilla, .LG., Apostolidis, E., Genovese, M.I. (2009). Evaluation of indigenous grains from the Peruvian Andean region for antidiabetes and antihypertension potential using in vitro methods. J Med Food. 12(4):704-713. 2009.

[48] Umar, M.J. (2006). Improvement of the nutritional quality of a traditional complementary porridge made of fermented yellow maize (Zea mays): effect of maize-legume combinations and traditional processing methods. Food Nutr Bull. 28(1):23-34.

[49] Bodi, Z. (2008). Ferric ion reducing antioxidant capacity of yellow maize genotypes (Zea mays L. convarietas dentiformis). Növénytermelés (Crop Production) Tom. 3:236241.

[50] Anonymous. (1974). Biological Specification for Foodprinciples and Specific Applications. University of Toronto Press, Canada.

[51] Berggren, G.G. (1982). Questions and answers about weaning. Food Nutr., 4: 20-24.

[52] Cameroon, M. and Y., Hofvander, (1971). Manual on Feeding Infants and Young Children.

[53] Harper, L. (2003). Development of weaning food formulations based on cereal. Int. J. Food Sci. Technol., 3: 24-28.

[54] Iqbal, A. A., Ateeq, I.A., Khalil, S., and Saleemmullah, S. (2006). Physicochemical characteristics and amino acid profile of chickpea cultivars grown in Pakistan. Foodservice Res. Int.; 17: 94-101.

[55] Lanna, A.C., Jose, I.C., Oliveira, M.G., Barros, E.G. and Moreira, M.A. (2005). Effect of temperature on polyunsaturated fatty acid accumulation in soybean seeds. Braz. J. Plant Physiol., 17: 213-222.

[56] Nelson, S.S. (1992). Introduction to the Chemical Analysis of Foods. International Thomson Publishing, New York, Pp: 93-96.

[57] Ngeh-Ngwainbi, J., Lin, J and Chandler, A. (1997). Determination of total, saturated, unsaturated and monounsaturated fats in cereal products by acid hydrolysis and capillary gas chromatography. J. AOAC Int., 80: 359-372.

[58] Oduro, I., Ellis, W., Sulemana, A. and Oti-Boateng, P. (2007). Breakfast meal from breadfruit and soybean composite. Discovery Innovat., 19: 238-242.

[59] Rombouts, F.M. and Nout, M.J.R. (1995). Microbial fermentation in the production of plant foods. J. Applied Bacteriol., 179: 1085-1175. 
[60] Sanni, A.I., Onilude, A.A. and Ibidapo, T.I. (1999). Biochemical composition of infant weaning food fabricated from fermented blends of cereal and soybean. Food Chem., 65: 35-39.
[61] Shewry, P.R. (2007). Improving the protein content and composition of cereal grain. J. Cereal Sci., 46: 239-250. 